\title{
THE MOLDOVAN BANK FRAUD (2012-2015). \\ A process tracing analysis of the Moldovan \$1 billion money laundering
}

\section{Alexandrina VARZARI', Bachelor of International Business and Politics, Copenhagen Business School, Danemarca}

\author{
DOI: https://doi.org/10.36004/nier.es.2020.2-08 \\ JEL Classification: D73, E5, F5, F15 \\ UDC: 343.359(478)
}

\section{ABSTRACT}

In the 2012-2015 period, $\$ 1$ billion have been stolen from three Moldovan banks, which is the equivalent of $12 \%$ of the country's GDP. The highly fraudulent environment in the RM allowed for the successful application of fraudulent schemes for three years, without it being seized and frozen. This paper seeks to decipher the schemes that were applied as well as argue how the integration into the European Union would have lowered the corruption and thereby prevent the fraud from happening. Even though several scholars discussed the bank fraud and how it affected the relationship between Moldova and the EU, they do not address how the steps of integration into the European Union could gradually regulate the level of corruption in the RM and subsequently eliminate the possible methods of committing the bank fraud. Through a comparative analysis of Romania and the Republic of Moldova, I aim to demonstrate that the difference between the level of corruption and the stability of the banking system in these two countries is due to EU membership. Further, through secondary analysis of qualitative data, and semi-constructed interviews, I conclude that, in theory, my argument holds - the instruments the EU applies on the candidate countries would not have allowed the fraudulent schemes to be put into action. However, the EU failed to apply the conditionality concept on Romania and thus, it is possible that the money laundering in the RM could have happened even if it had been a member of the EU.

Keywords: bank fraud, Republic of Moldova, European Union; international relations, corruption, European integration.

După perioada 2012-2015, Republica Moldova a intrat într-o perioadă de stagnare economică din cauza fraudei bancare de 1 miliard de dolari, ceea ce reprezintă echivalentul a 12\% din PIB-ul țării. Mediul extrem de fraudulos din RM a permis aplicarea cu succes a schemelor frauduloase timp de trei ani, fără a fi sesizate și înghețate. Această lucrare urmărește să descifreze schemele care au fost aplicate, precum și să argumenteze modul în care integrarea în UE ar fi scăzut corupția și, prin urmare, ar fi prevenit frauda. Chiar dacă mai mulți savanți au discutat despre frauda bancară și despre modul în care aceasta a afectat relația dintre Moldova și UE, aceștia nu abordează modul în care etapele de integrare în Uniunea Europeană ar putea reglementa treptat nivelul corupției din RM și ulterior elimina posibilele metode de comiterea fraudei bancare. Printr-o analiză comparativă a României și a Republicii Moldova, demonstrez că diferența dintre nivelul corupției și stabilitatea sistemului bancar din aceste două țări se datorează statutului de membru al UE. Mai mult, prin analiza secundară a datelor calitative și interviurilor, concluzionez că, teoretic, argumentul meu este valabil. Pe de altă parte, bazându-ne pe exemple empirice, UE nu a reușit să aplice conceptul de condiționalitate în România. Prin urmare, este posibil ca spălarea banilor în RM să se fi putut întâmpla chiar dacă ar fi fost membru al UE.

Cuvinte-cheie: fraudă bancară, Republica Moldova, Uniunea Europeană, relații internaționale, corupție, integrare europeană.

В период 2012-2015 годов из трех молдавских банков был украден 1 миллиард долларов, что эквивалентно 12\% ВВП страны. Среда с высокой степенью коррупций в РМ позволила незаметно применять мошеннические схемы в течение трех лет. В этой статье расшифрованы применённые

${ }^{1}$ ID ORCI 0000-0001-8504-1271, \e-mail: alexandrinavarzari135@gmail.com

December No. 2/2020 
схемы, а также показано, как интеграция в ЕС снизила бы коррупцию и, таким образом, предотвратила бы мошенничество. Несмотря на то, что ученые обсуждали банковское мошенничество и то, как оно повлияло на отношения между Молдовой и ЕС, они не рассматривали, как шаги интеграции в Европейский Союз могли бы постепенно регулировать уровень коррупции в РМ и впоследствии устранить возможные методы совершение банковского мошенничества. Путем сравнительного анализа Румынии и Республики Молдова эта статья демонстрирует, что разница между уровнем коррупции и стабильностью банковской системы в этих двух странах обусловлена членством в ЕС. Кроме того, путем вторичного анализа качественных данных и интервью я прихожу квыводу, что теоретически мои аргументы верны, в то время как на самом деле ЕС не смог применить концепцию обусловленности в Румынии. Таким образом, не исключено, чтоо отмывание денег в РМ могло произойти, даже если бы она была членом EC.

Ключевые слова: банковское мошенничество, Республика Молдова, ЕВРОСОЮЗ, международные отношения; коррупция, Европейская интеграция.

\section{INTRODUCTION}

Since the time of its establishment, the European Union has lived through a striking dimensional expansion with the completion of the essential elements of the European project. EU enlargement has started with the 6 founding states - Germany, France, Italy, the Netherlands, Belgium, Luxemburg - and it has gone through a series of evolutionary stages, reaching 27 member states. The Republic of Moldova is approached through the prism of the European Neighbourhood Policy, launched by the European Commission in May 2004 in response to the EU enlargement to the east and the need to avoid a new division of Europe (EEAS, 2016). Moldova's European path is certainly more difficult and much more radical compared to the experiences of other Member States, especially because of the high level of corruption. In this research paper I will reveal how the European Union institutions such as the European Commission and the European Council shape the political and economic behaviour of candidate countries, and especially of countries from Central and Eastern Europe, through the accession treaty, the process of negotiation and acquis communautaire. Seeing that the $\mathrm{EU}$ institutions dictate the rules of the game, I want to uncover what the game is and learn how it is played. (Steinmo, 2001).

The theft of the billion in the RM was an intricate process, which was successful on the strength of the complex schemes, applied in the 2012-2015 period. The schemes involved the rotation of a small amount of liquidity amongst three national banks - Social Bank, Unibank and Economy Bank. This event is accompanied by the liquidation of other numerous banks over the years, and so far, no efficient and transparent mechanism has been developed that would prevent fraud in the process of liquidating banks. For this reason, I examine the possibility that the theft would not have happened if the Republic Moldova had joined the European Union before the bank fraud. Theoretically, corruption should decrease considerably in a candidate country and such events as money laundering amounting to such colossal sums should not be possible. With this in mind, I put forward the following research question:

„How could the integration to the European Union prevent the bank fraud schemes of 2012-2015 in the Republic of Moldova?"

Likewise, my line of argument is that if the RM had implemented and respected all the requirements imposed on an applicant country to join the EU, the level of corruption would have declined, and the bank fraud would not have happened.

To answer the research question, I will first introduce you to the empirical background and tell why there is so much corruption in the RM. Next, I will discuss the theories on which I based my line of argument and my methodology choices. Following the methodology part, I will move to the analysis of this study, where I will present my findings and discuss if they confirm the theory. Lastly, I will develop the conclusion and reflect on how my theory, methodology and findings match.

\section{LITERATURE REVIEW}

Briefly presenting the Republic of Moldova from its historic context will help shed light and explain why there is so much corruption, why it was possible to carry out the bank fraud in the first place as well as why the European integration has been and still is such a long process for the RM. The RM has a rich history which plays a great role in its actual international, political and economic situation. The country is a relatively young, independent, developing state which has its origins in the Soviet Union and the Greater Romania. The 
phenomenon of corruption has, for a long time now, been a big problem for Moldovan society. It has spread and infected all areas, institutions and the Moldovan community and it poses a major danger to the prosperity of the state and its economic, social and democratic development. The period that favoured the establishment and the growth of corruption in the country is comprised within the end of the 1980s and the beginning of the 1990s. This timeframe is characterized by the Moldovan transition and adaptation from an autocratic to a democratic regime and market economy. It is well known that these kinds of transitions are often accompanied by serious consequences, such as the escalation of corruption, if the society is in crisis (EJOVA \& Prijilevscaia, 2012).

Corruption increased even more due to the 1998 regional crisis when Russia experienced a decrease in raw material prices, which amounted to $80 \%$ of Russia's export. Since Moldovan economy was heavily dependent on Russia's, it pushed $70 \%$ of the population into absolute poverty and $50 \%$ of the population into extreme poverty (Negură, 2016). In such an unhealthy economic environment, the Communist Party came to power, supported by a disappointed society with the present power structures and nostalgia for the previous political order. (Negură, 2016). The fierce transformations that the Moldovan society has undergone - such as deportations, industrialization, collectivization and famine - have created deep social and economic inequalities. These transformations have brought Moldova into a deep stalemate that seemed impossible to overcome in the period prior to the bank fraud. At the same time, all institutions were captured and controlled by politicians who did not want any change and had a major interest in maintaining the status quo. Thereby, there was no intellectuality, cohesive vision, or even a plan on how the Republic of Moldova should function further. There was vast instability in society on whether the country should join either the EU, or the Customs Union or any other entity imposed by the Russian Federation, or should seek union with Romania. There was no country project or a well-structured agenda for further actions (Negura, Sprinceana, \& Ernu, 2016).

The neo-functionalist theory was developed by Ernst B. Haas. The core concept of this theory associated with European integration is 'spillover'. It refers to the process when cooperating countries that pursue a specific goal end up formulating new goals that need to be achieved to reach the original goal (Jensen, 2018). Applied to the case of the Republic of Moldova, the state aims to join the European Union with the ultimate goal of implementing changes for the better at the political, economic, and cultural levels, but also to have access to the single market. However, since the country faces such considerable problems as corruption, to achieve its goal it must set new political goals in the field of justice, for instance, to defeat this obstacle and become a Member State.

If the Moldovan state had implemented the Copenhagen criteria and parts of the acquis communautaire before the bank fraud, it would have gone through a gradual transition from a deep-rooted post-Soviet mentality, which gave rise to the corruption phenomenon, to European democratic current affairs. Consequently, the bank fraud most probably would not have happened. This argument was developed on the grounds of the top-down Europeanization theory. Hypothetically, the top-down phenomenon describes how the EU restructures institutions, processes and political outcomes in candidate countries (Börzel \& Panke, 2018). I thereby assume that if the RM had decided to join the European community, the EU would have caused domestic changes because of the nonconformity in beliefs and institutions between the economic community and the candidate state. Top-down Europeanization has proven very efficient in shaping policies, politics and polity in cases of unstable democracy and new-comers, such as CEE countries. All the same, it is possible that a Member State might attempt a democratic backsliding, which demonstrates that Europeanization is not an irreversible process. For instance, the Hungarian Prime Minister made an attempt to reverse the institutional changes that were implemented as a condition of EU membership (Börzel \& Panke, 2018). Yet, there are very few such cases.

The European Union conditionality is, in practice, the ability to influence the behaviour of a candidate country by making attractive offers under a specific condition or set of conditions. In the case of the RM, the attractive offer is to join the EU and the condition is, among others, to fight corruption. It is a mechanism that has been used with all the Central and Eastern European (CEE) countries. It is important to add that the conditions for CEE countries are much more detailed and comprehensive than for other countries. To illustrate, international financial institutions, such as the IMF or World Bank can offer financial benefits with the condition that a country implements specific economic policies (Grabbe, 2002). The set of conditions that are proposed to CEE countries are clear and fixed, as opposed to the highly politicized, complex and less clear

December No. 2/2020 
conditions imposed by the EU (Grabbe, 2002). Further, once these states join the EU, there is no clear mechanism to monitor corruption and sometimes the phenomenon comes back.

\section{DATA SOURCES AND USED METHODS}

The Method of Difference is one of the four modern comparative methods developed by John Stuart Mill. According to Mill, the world is consistent and there is a causal regularity underneath what seems to be an irregularity or a "confusing surface of things" (Moses \& Knutsen, 2012). These causal regularities can be discovered by applying scientific methods of systematic comparison over areas. Thereby, in this research paper, I will compare the political and social welfare in Romania and the Republic of Moldova. I will focus on the level of corruption and the actions Romania has taken to prevent money laundering in the context of EU conditionality. These countries are relatively similar and share several common features such as culture, language and history, but are significantly different in levels of wealth, social welfare and political position. This paper assumes that, among others, the European Union membership accounts for this significant inequality between these two neighbouring countries. The presence of this explanatory factor in Romania and its absence in the RM can be used to explain the variation in such outcomes as the level of corruption and state welfare. One should, nevertheless, consider these two shortcomings when applying the comparative methods: over-determination and sampling bias. Both deficiencies can lead to erroneous conclusions about the world. Thus, I will combine the deductive and inductive approaches to "test hypothesis concerning causal arguments even when the number of observations is relatively small” (Moses \& Knutsen, 2012).

Process tracing serves to find a causal relationship between an independent variable and the outcome of a phenomenon in the social world. In the present study, this process will help identify how the high level of corruption led to the "theft of the century" in the RM. I developed a causal relationship between corruption and the bank fraud of 2014 and analysed the causal mechanism connecting the two concepts. By definition, process tracing implies "attempts to identify the intervening causal process - the causal chain and causal mechanism - between an independent variable and the outcome of the dependent variable" (Beach \& Pedersen, 2013). I will employ the explaining outcome process analysis, which is case-centric and can be thought of as a single-outcome study (Beach \& Pedersen, 2013). I used it to explain how the mechanisms to produce this fraud were put into action.

To answer the research question of this paper I collected data from primary and secondary sources in a qualitative manner. I conducted semi-structured interviews, analysed academic documents and papers as well as theoretical reflections of such scholars as Ernst B. Haas, Börzel and Panke, Steinmo on Hall as well as Grabbe. Mostly, I collected data about the bank fraud from a report constructed by Kroll Associates UK Limited, registered in the United Kingdom, which was selected by the National Bank of Moldova to conduct preliminary investigations into alleged financial irregularities at the three Moldovan banks (Sîrbu, 2015). Thanks to it, some of the persons and companies that participated in the money laundering were revealed and were later imprisoned. Doubtless, since it is not a report made by Moldovan institutions but a third party, I think it is highly trustworthy. Moreover, I analysed the accession treaty of Romania to predict what reforms would the RM have gone through as a candidate country. I choose the Romanian access treaty for the reason that the country is the most similar to the RM in ethnographic aspects. To collect qualitative, primary data I conducted semi-structured interviews. What made semi-structured interviews attractive is that the interviewer could depart from the list of questions if it was relevant and important (Bryman, 2012). Secondly, it allows accumulating solid facts from experts in the domain. In the interest of obtaining reliable information, I interviewed Moldovan economy expert Viorel Gîrbu.

\section{RESULTS OF OWN RESEARCH AND DISCUSSIONS}

Bank Fraud. Schemes and Methods

The first aspect to point out is that the money laundering process of $\$ 1$ billion from the three national banks unfolded in two phases: 1 . The acquisition of the banks; 2 . The perpetration of fraud schemes. Further, I will describe each of the phases.

The acquisition of the three banks 2012-2013

The Acquisition of Unibank (UB)

Between 2007 and 2012 the share structure of UB was composed principally of a single significant shareholder - Vienna Capital Partners Unternehmensberatungs AG, based in Austria. On 17 August 2012, 8 UK-registered companies, 12 Moldovan and 1 Russian citizen became the new shareholders of the bank, 
each owning a stake of between $4.5 \%$ and $4.99 \%$. At that moment, none of them could buy a stake in a bank of $5 \%$ or above, because conform the Moldovan law a person who holds a stake of $5 \%$ and above is considered a significant shareholder and requires formal approval from the National Bank of Moldova (Moldova, 2012). The source of funds used to purchase UB shares was loans from corporate entities, that wired funds through banks in Latvia, a non-OECD country. The same corporate entity was used to fund not only one but several shareholders. Further, in seven cases, shareholders individuals financed their purchase of UB shares with loans from an entity that had direct links to Ilan Shor, one of the suspects involved in the fraud (Kroll, 2015). The NBM and the Kroll report could not clearly identify how shareholder companies funded their share acquisitions, because they were shell companies and the declared beneficiaries were nominees. Thus, we could assume that their ultimate ownership of the shares was intentionally hidden (Kroll, 2015).

\section{The acquisition of Social Bank (SB)}

Prior to its acquisition in 2013, SB was owned by numerous minority shareholders who are apparently unrelated. As a result of the sale, $50 \%$ of the bank's share capital was transferred to Moldovan, Russian and Ukrainian individuals as well as Moldova-based companies. Again, each of them did not hold $5 \%$ or more of the shares, as this would have required National Bank of Moldova approval. Reminiscent of Unibank, SB most shareholders had the role of nominees to mask the real beneficiaries. While some had close ties to Ilan Shor, others had profiles that did not match a typical investor who would be interested in purchasing stakes in a Moldovan bank, with their acquisition being financed through loans from offshore entities. All these individuals seem unrelated at first sight, but they actually share one noteworthy fact - the funding of share acquisition. The companies and individuals who acquired shares in the bank financed their acquisition through multiple offshore shell companies with common addresses and Latvian bank accounts (Kroll, 2015).

The acquisition of Economy Bank (BEM)

In 2013, the Moldovan state had had a majority stake of 56.12\% in BEM. The BEM had liquidity shortfall because of a growing non-performing loan portfolio. The bank's exposure at that time was mainly Moldovan companies (Kroll, 2015). The solution that was applied was share issuing to raise capital. Regardless, the Moldovan state did not have enough funds or, according to the economy expert Viorel Gîrbu, it simply did not want to acquire any additional shares (Gîrbu, 2:56). Consequently, the shares of the state were reduced to a blocking stake of 33.3(3)\% plus one share. Then, an existing shareholder bought the number of shares lost by the state, reaching $33.8 \%$ and the rest were acquired by various Russian individuals via offshore entities. In a similar manner as that regarding BS and UB, not only did the shareholders had the same sources of funding, but also used their shares in BEM to guarantee loans issued by BS to various Moldovan companies.

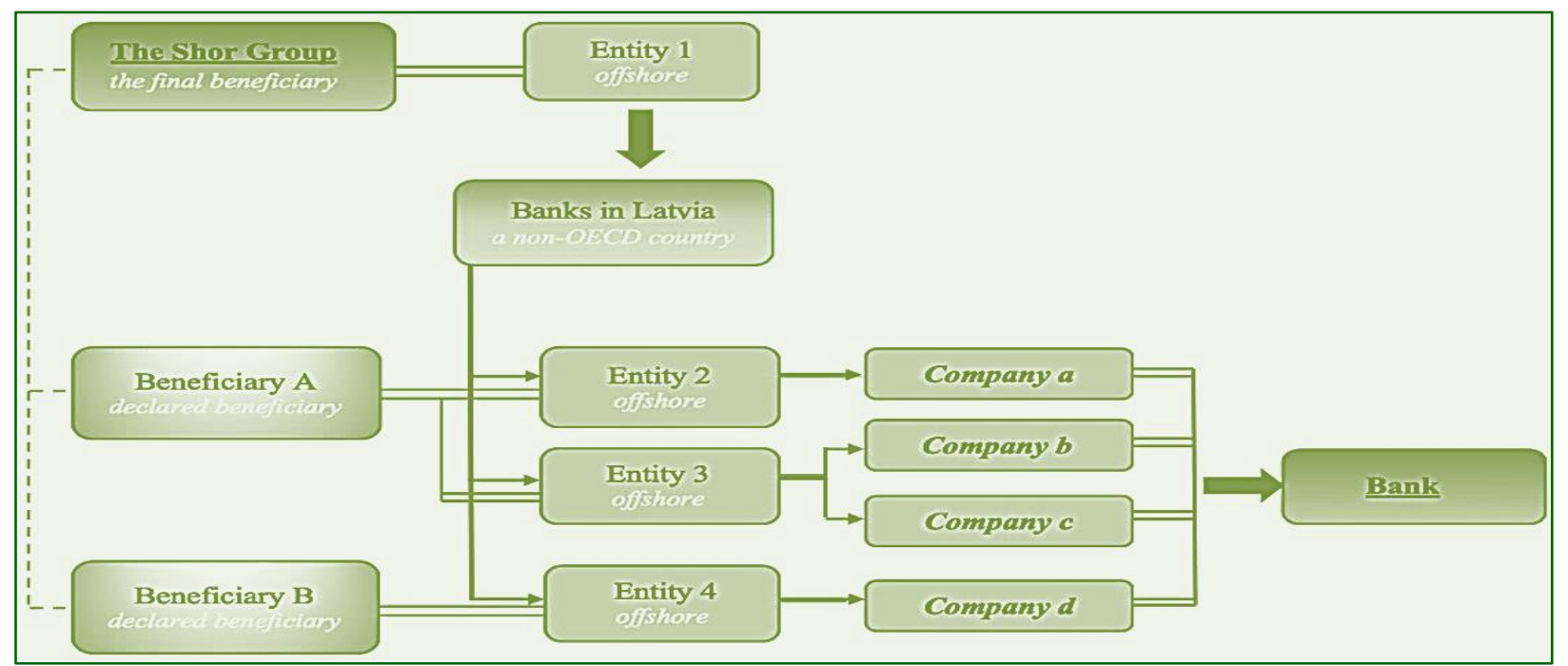

Figure 1. A summary of the ownership structure of the Shor Group and the ways of financing the acquisition of the three banks

Source: Elaborated by the author.

December No. 2/2020 
Figure 1 summarises the process of how he Unibank, Banca Socială and Banca de Economii shares have been bought. It illustrates the ownership structure of the Shor Group, which executed the bank fraud, as well as the method of financing the purchase of shares in the three Moldovan banks. The first aspect to point out is that the Shor Group, the final beneficiary of the bank fraud, tried to disguise its attempt to gain control over the banks. In order to do so, it enshrouded the fact that it was the final beneficiary of the Moldovan firms that were involved in the share acquisition by employing nominees or, as shown in Figure 1, declared beneficiaries. The connection between the declared beneficiaries and the Shor Group was kept in secret and this is represented by the blue dashed lines in the figure. At the same time, the blue straight lines show the ownership links. The flow of funds utilized to finance the share purchase is in red arrows. Shortly, the Shor Group instructed the offshore companies that it owns to wire funds through Latvian banks, a country out of the OECD zone, to the offshore entities. These, in turn, directly controlled the Moldovan individuals and companies that used the money to buy shares in the three financial institutions (Monahov \& Jobert, 2017).

The perpetration of fraud schemes and money laundering - 2014-2015

At this point we will analyse the schemes applied by the Shor Group in the successful money laundering at greater detail. To begin with, the main goals behind the schemes were to:

- "maximize available liquidity for banks to lend to controlled firms

- prevent prudential indicators from deteriorating to avoid supervision from Central Bank

- extract money from the Moldovan financial system by laundering it to non- OECD banks" (Monahov \& Jobert, 2017)

Scheme 1

The first scheme, also known as the "Roseau transaction", was put in action shortly after obtaining control over Banca de Economii. The origin of this name comes from the transaction performed by the financial institution of a part of its non-performing loan (NPL) portfolio to a UK based entity, Roseau Alliance LLP. It is unclear why this entity agreed to buy the entire NPL portfolio at face value and thereby effectively cancelling the "distressed assets" of BEM in exchange for cash (Kroll, 2015). Moreover, this company had been incorporated only one year before this transaction was held. For this reason, the Roseau Alliance entity is considered an investment vehicle/shell company that is also under the control of the holding company (Kroll, 2015). Consequently, the purpose of this transaction was to maximize the capacity of the bank to lend to companies and individuals controlled by the Shor Group (Monahov \& Jobert, 2017).

\section{Scheme 2}

The second scheme applied by the Shor Group was loan shifting between client groups, firms and banks. The goal they wanted to achieve when shifting loans between firms was to "build trust in the form of a sound credit record allowing the controlled firms to request increasingly large amounts of credit without raising suspicion" (Monahov \& Jobert, 2017). To do so, four strategies were employed:

1. "firms systematically borrowed money from any one of the three banks;

2. they have transferred the money to a firm whose credit was due to mature in the near future and

3. the firm whose credit matured repaid the loan, only to

4. later borrow again to repay another firm's loan" (Monahov \& Jobert, 2017).

The amount borrowed by firms was increasing every time they requested money from financial institutions with these, in turn, demonstrating healthy statistics in the allocated credits. The Shor Group was able to successfully use this scheme for a longer period without being detected thanks to two significant factors. First of all, there was a large number of firms and banks involved in this procedure and secondly, the funds transferred between the controlled firms were done through offshore entities. Accordingly, it was challenging at that instant to track linkages between the firms controlled by the holding company. Moreover, as long as the banks were receiving funds back, their liquidity was increasing, which enabled them to increase lending.

\section{Scheme 3}

Another means that the holding company employed to temporary improve the prudential indicators was loan shifting in the ranks of client categories. The reason it succeeded is that the banks 
insensibly decreased its exposure to non-controlled firms. This resulted in increased liquidity and the bank was more exposed to offer credit loans to controlled firms. However, the bank's "Large" Exposures standard increased (Monahov \& Jobert, 2017), which means that the financial institution exposes itself too much to individual clients or groups of connected clients (EBA, 2020).

\section{Scheme 4}

The next method used was the Circular Bank Deposit Scheme. It had the same purpose as the others above: to diminish the aggravation of prudential indicators in the wake of loan issuance. This scheme was developed on the basis of the regulatory norms which affirms that if "a firm provides bank deposits as collateral for any given loan, then the loan's risk weighting is diminished to reflect the existence of collateral". In such a way, the bank's Capital Adequacy Ratio would decrease slower as long as the debtor provides collateral when requesting a credit. However, shell companies do not have capital at their disposal and thus are not capable to turn it into bank deposits. For this reason, the scheme was applied in such way that at least two banks opened a "deposit account with own funds in the name of the company to be credited" (Monahov \& Jobert, 2017), so that the company can then present the documents to the bank it requests the credit from. Once the prudential indicator improves, the financial institution can issue more credits until it reaches the regulatory limits. Further, after the bank receives the deposit it issues similar deposits. Through this scheme, money can be "reused" endlessly to lower risk weights for loans (Monahov \& Jobert, 2017).

\section{Scheme 5}

The last scheme finalized the process of money laundering by maximizing the available liquidity. The method is quite simple and straightforward: the banks that were under the control of the holding company borrowed money from other Moldovan non-controlled banks. In the financial environment of the time, non-controlled banks which had high liquidity were willing to lend because loan demand was weak, interest rates were low and there was no risk that the receiving institutions would not repay. But even if they failed at that point, there was a general expectation in the Moldovan financial environment that if a banking institution faced a failure, it would be saved anyway. That is why Moldovan banks often agreed to engage in interbank lending, and thus the controlled banks took advantage of this and borrowed large sums of money for long periods (Monahov \& Jobert, 2017).

\section{Analysis}

Next, I will analyse how the EU strategy of enlargement to the CEE countries would have shaped the political and economic behaviour in Moldova. In order to open the EU accession negotiations, a country must meet the first Copenhagen criterion - institution building, which is a process of "training and equipping a wide range of civil servants, public officials, professionals and relevant private sector actors" (European Commission, 2001). A way to establish such institutions is through the twinning instruments, which were applied to the 2007 joining of Romania. By definition, it means that a country in the pre-accession stage can install "modern and efficient administrations, with the same structures, human resources and management skills similar to ones that already exist in the Member States" (European Commission, 2001). To illustrate, Romania has established the National Anti-Corruption Directorate (DNA) on the example of Spain. This institution is in the top five anti-corruption institutions in the EU and has achieved impressive results in "solving high and medium level corruption cases" (European Commission, 2017). This means that the implementation of an institution such as the DNA in the RM would have been necessary in its pre-accession period.

The second and more complex stage is the negotiations, which require reforms in all 35 chapters of the acquis communautaire. I will only analyze the ones that relate to the bank fraud. I will begin with chapter 9: Financial Services. This chapter refers to the compliance of the regulations in the field of financial services, namely the banking services with the EU acquis. The objective of this chapter of the acquis is to establish a high level of stability, security and efficiency in the financial system of the adherent countries, so they meet European requirements in the field of financial services. The National Bank of Moldova is the regulatory authority of the banking financial sector and has the power source to promote changes in the field to align banking operations with European requirements. Consequently, the institution would have to implement specific changes in the sector relying on the following reference document implemented in the European Union: Core Principles for Effective Banking Supervision. These principles have the purpose to reinforce the global financial system and eliminate weaknesses in 
the banking system within a country (Basel Committee on Banking Supervision). In total, there are 29 principles, but I discuss the most efficient ones for this case:

- Principle 6: Transfer of significant ownership. "The supervisor has the power to review, reject and impose prudential conditions on any proposals to transfer significant ownership or controlling interests held directly or indirectly in existing banks to other parties".

Under prudential review and conditions imposed, the major ownership restructure of the Unibank would have attracted the attention of NBM. The purchase of the UB shares by 21 identities, with a stake between $4.5 \%$ and $5 \%$ each is suspicious and thus, with external assistance, the NBM would have been able to identify the dubious share transfer to the Shor Group and reject it.

- Principle 19: Concentration risk and large exposure limits. "The supervisor determines that banks have adequate policies and processes to identify, measure, evaluate, monitor, report and control or mitigate concentrations of risk on a timely basis. Supervisors set prudential limits to restrict bank exposures to single counterparties or groups of connected counterparties".

Such supervision from NBM would have prevented the three Moldovan banks to expose themselves only to firms and individuals controlled by the Shor Group.

- Principle 29: Abuse of financial services. "The supervisor determines that banks have adequate policies and processes, including strict customer due diligence rules to promote high ethical and professional standards in the financial sector and prevent the bank from being used, intentionally or unintentionally, for criminal activities" (Basel Committee on Banking Supervision, 2012).

This principle is crucial, because one of the main reasons the bank fraud was successful is the lack of means to track and evaluate the financial institutions' counterparties. If the NBM would have had the tools to access such information, it could have determined the linkage between companies, clients and banks, but also its profiles. For example, many individuals did not represent investor profiles, and several companies controlled by the holding company had been inaugurated a year before the schemes were applied.

The next chapter of the acquis that we shall take into consideration is chapter 24: Justice and home affairs. Among other things, European policies seek to fight internationally organized crime. Thereby, Member States must be adequately equipped to be able to comply with Union rules (European Commission). In the pre-accession period, countries must successfully integrate law enforcement agencies and other relevant bodies with efficient and strong functioning capacity. In 1993, the EU implemented three new instruments to ensure justice across the area. One of them is the most important to this study: a Convention. For example - Europol, whose responsibilities include to "streamline the competent authorities of the Member States and strengthen cooperation in the following area(s): money laundering associated with international criminal activities" (România, 2005). Equally important, the liaison officers within this institution work both in the member countries and in the countries outside the area. They are responsible for collecting information and communicating directly to the competent authorities about fraudulent acts in the host country. Cooperating with Europol would have helped to annihilate operation "Titirezul", as it proved to be efficient in similar frauds. For instance, Europol helped the Spanish Guardia civil in operation "Usura" to stop money laundering schemes linked to two famous Russian criminal syndicates (EUROPOL).

A comparative analysis between Romania and Moldova

One of the main differences between Romania and the RM in the period before the bank fraud was the level of corruption and the functioning of the bank sector. According to the Corruption Perception Index (CPI), in 2012, Romania's score was 44/100, while Moldova's was 36/100 (CPI, 2012). At first sight, it might not appear as a big difference, but if we compare the level of corruption in Romania before it joined the EU, we will seize the result of the EU conditionality mechanism. Indeed, in 2004 Romania has scored 29/100, as reported by CPI, corruption being a significant problem for the country and its population. Moreover, the accession to the EU has shown a positive impact on the banking system. After 2007, the National Bank of Romania (NBR) strengthened its performance, becoming more efficient as it became a member of the European System of Central Banks (Dragan, 2010). The NBR, in the role of the main supervisor, has been able to efficiently monitor the national banks and has implemented "new measures to improve the prudential regulatory 
framework and in collaboration with the Government signed some funding agreements with the IMF and the EU" (Dragan, 2010). This resulted in a healthy, safer banking market. The Moldovan highly corrupted environment resulted in the money laundering of $\$ 1$ billion, especially because of the lack of effective supervision, cooperation of the National Bank of Moldova with national and international agencies as well as prudential conditions. We can thus conclude that the explanatory factor in such contradictory outcomes is EU integration.

\section{Counterargument}

The accession of Romania to the EU might have shown positive progress towards fighting corruption and prevent money laundering, but its journey was not accompanied by a coherent policy against corruption. The problem was that the European Union has not developed an ample scenery against corruption for candidate countries. Even though in 1998 it established new strategies to evaluate the anti-corruption efforts in the CEE countries, it did not develop an effective way to evaluate these strategies. Besides, the Commission did not communicate these strategies in a clear, systematic manner in a single document to the candidate countries. The EU understood these weaknesses thus reinforced its strategies towards the accession of Romania (Szarek-Mason, 2010). The reinforced strategies included the possibility to postpone the year of accession if the countries were not prepared to meet the conditions of membership; and the implementation of a monitoring mechanism that verifies the progress in combatting corruption after the countries had joined the EU (Szarek-Mason, 2010). Even under such conditions, the 2005 and 2006 reports have shown that corruption was still a significant, widespread problem and there have not been significant improvements. However, this did not result in the postponement condition. Even with further monitoring strategies, Romania failed to meet the requirement. Consequently, the reinforced strategies of the EU Commission proved to be ineffective (Szarek-Mason, 2010).

Equally relevant is the fact that the Republic of Moldova could have joined the European Union even if it had failed to meet the conditions of membership. As economy expert Viorel Gârbu argues, in its European journey, the Republic of Moldova was at the same level as the Baltic states, which joined in 2004 and 2007. Similarly, if Romania succeeded to join, the RM would have succeeded as well. In addition, the financial institutions that participated in the bank fraud were from a European country, and those who participated have taken the necessary measures to cover and reap certain benefits regardless of the regulatory framework. According to Mr Gârbu, the European Union does not intervene so deeply in domestic policies and the implementation of the Romanian National Anticorruption Directorate was established because of effective leadership. He thinks that there was a person "who wanted to fight corruption, but that person was not named by the EU. They were not delegated by the EU". What's more, as the economy expert says, even though the RM was a Member State, the bank fraud could still happen, and the EU would not have taken any measures. The EU would not have cut monetary donations, because it would lose its leverage: "For donors, money is not important, politics is important and also is the possibility to intervene in politics" (Gârbu, 2020).

\section{DISCUSSION}

I will now continue with a concluding discussion on how the theories and findings harmonize, with little dispute. First, to access the single market, the Republic of Moldova would have to meet the first Copenhagen criterion, a fact that coincides with the concept of spillover. As discussed earlier, the EU applies the twinning tool to help a candidate country implement effective institutions following the example of a Member State. Thus, Moldova would have to resort to the help of a Member State to develop a modern and efficient administration as well as implement legislative and institutional models that work well. Following the fulfilment of the Copenhagen criteria condition, the RM would move to the negotiations stage, that is an appropriate example of Top-Down Europeanization. Both chapters 9 and 24 that are negotiated address the problem of international organized crime and money laundering and the measures that should be applied to prevent a violation of the banking system. The Core Principles for Effective Banking Supervision offer instruments that are imposed by the Commission in the pre-accession period to establish a high level of stability, security and efficiency in the financial system of the adherent countries.

The European journey of Romania is a representation of the conditionality concept. In its preaccession period, the EU influenced its behaviour by imposing conditions to fight corruption. 
Unfortunately, in the case of Romania, the conditionality concept was not efficient. Even though the country had shown progress, such as the establishment of the National Anticorruption Directorate, it did not meet the conditions of membership. The EU imposed the condition that the country had to step up and to carry out certain reforms if it wanted to become a Member State or its accession would be postponed for a year. Romania did not meet the condition but still joined the EU in 2007. Thereby, we can assume that the Republic of Moldova could have joined the EU even with high records of corruption. Even if the EU tried to apply its strategy of monitoring the progress of Moldova in its attempts to fight corruption in the post-accession period, the findings show that no drastic consequences would have been applied. It is very possible, thus, that the bank fraud could still have happened.

\section{CONCLUSION}

This research paper aimed to test the theory that the integration to the European Union could prevent the bank fraud schemes of 2012-2015 in the Republic of Moldova. Through a deductive and inductive approach, we can conclude two main points. Firstly, in theory, if the Republic of Moldova had implemented the necessary instruments and conditions imposed by the EU regarding money laundering and banking system, it would have destroyed any possibility of putting the fraudulent schemes into action. Reforms in the banking system were necessary for the RM in order to establish a high level of stability, security and efficiency in the financial system. The National Bank of Moldova would have had to "set and enforce minimum prudential standards for banks and banking groups" (Basel Committee on Banking Supervision) which would have informed the supervisor when these standards are violated. Moreover, an effective supervision from the NBM, which would have cooperated with national and international agencies would have provided the opportunity to observe and stop the bank fraud, if not preventing it in advance. Especially because the NBM would have had the power to "review the overall activities of a banking group, both domestic and crossborder", this could have revealed its ways of transferring money abroad to finance the acquisition of shares in the bank. Moreover, cooperation with CEPOL would provide the NBM with innovative and advanced security and law enforcement training while cooperating with Europol, would offer assistance to the supervisor to collect information and "identify, prosecute, freeze or confiscate the instruments" of executing the bank fraud.

Secondly, based on Romania's experience of fulfilling the European conditions, we can conclude that the bank fraud could still have happened, even if the Republic of Moldova had joined the European Union. This is because the EU conditionality on post-communist countries' transition was general and indistinct. The EU did not have a distinct agenda, and its ways to influence the levels of government were not evident (Grabbe, 2002). As discussed before, even though Romania had been imposed to insure the fulfilment of numerous conditions for accession and several strategies to be verified upon, the country had not been provided with a clear plan and a comprehensive anticorruption framework. As a result, Romania had not succeeded to meet the requirements against corruption and international organised crime and no drastic sanction had been imposed. In fact, Romania received further support for anti-corruption reforms. Thereby, if the RM would have shared the same journey to access the single market, most probably there would have been little impediments to carry out money laundering.

\section{REFERENCES}

1. SPRÎNCEANĂ, V., NEGURĂ, P. Tranziţia în Republica Moldova: instrucţiuni de utilizare. Introducere. In: NEGURĂ, P., SPRÎNCEANĂ, V., ERNU, V. coord. Republica Moldova la 25 de ani: 0 încercare de bilanţ. Chişinău : Cartier, 2016, pp. 7-18. ISBN 978-9975-79-902-7, ISBN 978-997586-101-4.

2. NEGURĂ, P. Republica Moldova la un sfert de veac de tranziţie: între un comunism ratat şi un capitalism neînceput? In: NEGURĂ, P., SPRÎNCEANĂ, V., ERNU, V. coord. Republica Moldova la 25 de ani: 0 încercare de bilanţ. Chişinău : Cartier, 2016, pp. 35-39. ISBN 978-9975-79-902-7, ISBN 978-9975-86-101-4.

3. MOSES, J. W., KNUTSEN, T. L. The Comparative Method. The Methods if John Stuart Mill. In: MOSES, J. W., KNUTSEN, T. L. Ways of Knowing. Competing Methodologies in Social and Political 
Research. Poland: PALGRAVE, 2012. pp. 98-117. ISBN 978-0230360693.

4. BEACH, D., PEDERSEN, R. B. Working with Theories of Causal Mechanisms. Explaining-Outcome Process-Tracing. In: BEACH, D., PEDERSEN, R. B. Process-Tracing Methods: Foundations and Guidelines.University of Michigan Press. 2013, pp. 63-66. ISBN 978-0-472-05189-2. DOI: 10.3998/mpub.10072208

5. KROLL. Project Tenor - Scoping Phase: Final Report. National Bank of Moldova. London: Kroll, 2015. $84 \mathrm{p}$.

6. PARLAMENTUL REPUBLICII MOLDOVA. Legea instituţiilor financiare: nr. 550 din 21-07-1995. In: Monitorul Oficial al Republicii Moldova. 1996, nr. 1, art. 2 [citat 21 august 2020]. Disponibil: https://www.legis.md/cautare/getResults?doc_id=88466\&lang=ro\#

7. MONAHOV, A., JOBERT, T. Case study of the Moldovan Bank fraud: Is early Interventlon the Best Central Bank strategy to avoId fInanCIal Crises? Documents de travail GREDEG Working Paper Series. 2017, no. 7. 31 p.

8. EUROPEAN BANKING AUTHORITY. Large exposures. 2020 [citat 22 august 2020]. Disponibil: https://eba.europa.eu/regulation-and-policy/large-exposures

9. BÖRZEL, T. A., PANKE, D. Europeanization. In: EU Business and Polittics. B.Sc. International Business and Politics. Copenhagen: Academic Books, 2018, pp. 80-82.

10. JENSEN, C. S. Neo-functionalism. In: EU Business and Politics. B.Sc. International Business and Politics. Copenhagen: Academic Books, 2018, pp. 66-70.

11. GRABBE, H. European Union Conditionality and the Acquis Communautaire. In: International Political Science Review. 2002, vol 23, issue 3, pp. 249-268. ISSN 0192-5121.

12. SÎRBU, A. Raportul KROLL. Președintele Parlamentului. 2015, 04 may [citat 11 august 2020]. Disponibil: https://agora.md/stiri/8401/document--raportul-kroll--publicat-oficial-depresedintele-parlamentului

13. BRYMAN, A. Interviewing in qualitative research. In: BRYMAN, A. Social Research Methods. New York: Oxford University Press, 2012, pp. 469-471. ISBN 978-0-19-958805-3.

14. STEINMO, S. The New Institutionalism. In: CLARKE, P.B., FOWERAKER, J. ed. by. The Encyclopedia of Democratic Thought. 2001, pp. 560-565. ISBN 978-0415193962.

15. EUROPEAN COMISSION. Enlargement of the European Union. An historic opportunity. Brussels, 2001. 26 p. [citat 22 august 2020]. Disponibil: https://ec.europa.eu/neighbourhoodenlargement/sites/near/files/archives/pdf/press_corner/publications/corpus_en.pdf

16. EUROPEAN COMISSION. Report from the Commission to the European Parliament and the council. On Progress in Romania under the Cooperation and Verification Mechanism. 2017, 25 ianuarie. 14 p. [citat 14 septembrie 2020]. Disponibil: https://ec.europa.eu/info/sites/info/files/com-2017-44_en_1.pdf

17. CEPOL: misiune, viziune și valori. European Union Agency for Law Enforcement Training. 2020 [citat 11 septembrie 2020]. Disponibil: https://www.cepol.europa.eu/ro

18. EUROPOL. Money laundering [citat 21 august 2020]. Disponibil: https://www.europol.europa.eu/crime-areas-and-trends/crime-areas/economiccrime/money-laundering

19. EUROPEAN COMISSION. European Neighbourhood Policy And Enlargement Negotiations. Chapters of the acquis. 2019 [citat 21 august 2020]. Disponibil: https://ec.europa.eu/neighbourhood-enlargement/policy/conditions- membership/chaptersof-the-acquis_en

20. România, I. E. (2005). JUSTIȚIE ŞI AFACERI INTERNE. MasterPrint Super Offset.

21. EUROPEAN UNION EXTERNAL ACTION. EEAS. European Neighbourhood Policy (ENP). 2016, 21 decembrie [citat 19 august 2020]. Disponibil: https://eeas.europa.eu/diplomaticnetwork/european-neighbourhood-policy-enp/330/european-neighbourhood-policy-enp_en

22. EUROPEAN UNION. Chapter 9 - Financial services [citat 19 august 2020]. Disponibil: https://www.eu.me/en/9/item/476-chapter-9-financial-services

23. EJOVA, C., PRIJILEVSCAIA, N. Dimensiunea politică a colaborării internaţionale în combaterea corupţiei. In: Studia Universitatis. Seria Ştiinţe Sociale. 2012, nr. 3 (53), pp. 210-214. ISSN 18143199. 
24. BASEL COMMITTEE ON BANKING SUPERVISION. Core Principles for Effective Banking Supervision. Bank for International Settlements. 2012, septembrie. 85 p. ISBN 92-9131-146-4 [citat 19 octombrie 2020]. Disponibil: https://www.bis.org/publ/bcbs230.pdf

25. SZAREK-MASON, P. The EU anti-corruption strategy towards the Central and Eastern European candidate countries: achievement or missed opportunity? In: SZAREK-MASON, P. The European Union's Fight Against Corruption. The Evolving Policy Towards Member States and Candidate Countries. Cambridge: Cambridge University Press, 2010, pp. 185-217. ISBN 9780521113571.

26. TRANSPARENCY INTERNATIONAL. Corruption Perceptions Index. 2012 [citat 29 octombrie 2020]. Disponibil: https://www.transparency.org/en/cpi/2012/results

27. SZAREK-MASON, P. The impact of 2004 enlargement on the EU anti-corruption policy. In: SZAREK-MASON, P. The European Union's Fight Against Corruption. The Evolving Policy Towards Member States and Candidate Countries. Cambridge: Cambridge University Press, 2010, pp. 221-264. ISBN 9780521113571.

28. DRAGAN, O. R. The impact of European Integration on the Romanian Banking System. 2010, pp. 730-735 [citat 29 octombrie 2020]. Disponibil: https://www.researchgate.net/publication/49615416_THE_IMPACT_OF_EUROPE AN_INTEGRA TION_ON_THE_ROMANIAN_BANKING_SYSTEM/references

29. SZAREK-MASON, P. Conditionality in the EU accession process. Chapter 4. In: SZAREK-MASON, P. The European Union's Fight Against Corruption. The Evolving Policy Towards Member States and Candidate Countries. Cambridge: Cambridge University Press, 2010, pp. 135-156. ISBN 9780521113571. DOI: https://doi.org/10.1017/CBO9780511676086.005

30. GÂRBU, V. The Bank Fraud in the Republic of Moldova. 2020, 17 may.

\section{ARTICLE HISTORY}

Received 16 June 2020

Accepted 11 December 2020 